УДК 342:351

DOI https://doi.org/10.32837 / yuv.v0i3.1960

Л. Іщук,

аспірант кафедри кримінального права та правосуддя

Міжнародного економіко-гуманітарного університету імені академіка Степана Дем'янчука

\title{
ПУБЛІЧНЕ АДМІНІСТРУВАННЯ У ФІСКАЛЬНІЙ СФЕРІ: ТЕОРЕТИЧНІ ЗАСАДИ ТА ПІДХОДИ ДО ВИЗНАЧЕННЯ
}

Ефективність публічного адміністрування та укорінення в практиці управління державними справами в англосаксонських країнах призвело до його імплементації у державно-управлінську парадигму інших країн, особливо тих, які знаходяться на етапі зламу суспільної свідомості та переходу від ідеології тоталітаризму чи авторитаризму до демократіï [1, с. 11]. 3 розвитком державності та ускладненням правової системи все більше виявляється тенденція посилення ролі публічних засад у суспільному житті. У багатьох країнах спостерігається загальна закономірність визнання загальнонаціональної значущості публічної сфери та ролі держави в суспільному прогресі. У центрі уваги постає людина як громадянин розвинутої демократичної держави [2, с. 2].

Розвиток людиноцентристської моделі суспільства в Україні призвів до переосмислення державного управління та зумовив виникнення нових підходів до його розуміння. Саме в умовах глобалізації та євроінтеграційних процесів у західній та певною мірою і в українській науці про управління окреслилася зміна парадигми від розгляду процесу управління як «контролю над...» до його розуміння як «взаємодіï з...» i «скерування на...». Визначальним у цьому процесі стало визначення взаємозв'язків і відмінностей державного управління, публічного управління та публічного адміністрування [3, с. 8].
Виникнення та застосування поняття «публічне адміністрування» в Україні пов'язане з процесом трансформації системи державного управління, а також із процесом адаптації законодавства України до законодавства Європейського Союзу (далі EC) як пріоритетного напряму процесу інтеграції України до ЄC [4]. У Стратегії сталого розвитку «Україна-2020», говорячи про реформу державного управління, зазначалося, що результатом впровадження реформи у державному управлінні має стати створення ефективної, прозорої, відкритої та гнучкої структури публічної адміністрації із застосуванням новітніх інформаційно-комунікативних технологій (е-урядування), яка здатна виробляти i реалізовувати цілісну державну політику, спрямовану на суспільний сталий розвиток i адекватне реагування на внутрішні та зовнішні виклики [5].

Спочатку поняття «публічне адміністрування» ототожнювали з поняттям «державне управління» через переклад терміну "public administration". Однак згодом було досліджено, що це поняття має полісемантичний характер і залежно від контексту перекладається ще й як «публічне адміністрування», «публічна адміністрація» i навіть «суспільне управління», «управління на державному та місцевому рівнях» $[2$, с. 1$]$.

Широке використання поняття «адміністрування» призвело до того, 
що в це поняття вкладають різний зміст. Так, поняття «адміністрування» використовують для розкриття так званої «публічної сервісної» діяльності [6, с. 7], змісту управління та його механізму [7, с. 20-24]; стилю управління, за якого діяльність фокусується на процедурах і контролі за правильним виконанням розпоряджень [8, с. 27]; реформування виконавчо-розпорядчої діяльності держави [9, с. 22-30]; організаційно-правової діяльності окремих органів [10, с. 2-5]. В Енциклопедії державного управління адміністрування розглядається як управлінська діяльність посадових осіб, яка має чітко регламентовані функціі: прогнозування, планування, регулювання, контроль, комунікація, робота з кадрами, координація [11].

Публічне адміністрування - категорія, пов'язана із суспільно-корисною діяльністю осіб, найманих суспільством через владні інститути для діяльності щодо здійснення функцій у публічній сфері 3 метою забезпечення взаємодії суспільства, влади та економіки, досягнення суспільних інтересів. Публічне адміністрування покликане реалізувати принципи верховенства права і законності на засадах контролю з боку суспільства за діями державних органів, органів місцевого самоврядування, їх посадових осіб, спирається на такі цінності як професіоналізм управлінців, їхня політична нейтральність, порядність, уникання конфліктів інтересів; передбачає застосування принципів прозорості, особистої порядності, високих етичних стандартів, відповідальності, вільного доступу до інформації і солідарності з громадянами, забезпечення відповідної якості надання послуг i вміння пристосуватися до нових суспільних потреб [12, с. 201].

Публічне адміністрування відображає якісні зміни в характері виконавчо-розпорядчої, організуючої діяльності держави і визначається як діяльність публічної адміністрації з реалізації покладених на неї обов'язків і задоволення загальних публічних інтересів [13, с. $32 ; 14$, с. 12-13]. Поняття «Публічне адміністрування» має два тісно пов'язаних значення:

$1)$ це цілісний державний апарат (політика, правила, процедури, системи, організаційні структури, персонал тощо), який фінансують за рахунок Державного бюджету і який відповідає за управління та координацію роботи виконавчої гілки влади, iï взаємодію з іншими зацікавленими сторонами в державі, суспільстві та зовнішньому середовищі;

2) це управління та реалізація різних урядових заходів, пов'язаних із виконанням законів, постанов і рішень уряду та управління, яке стосується надання публічних послуг [15].

Таким чином, публічне адміністрування $€$ складником публічного управління, метою якого $є$ розвиток держави на засадах демократії з використанням ефективних новітніх методів і технологій управління, спрямованих на забезпечення громадян на рівні світових стандартів [2, с. 4]. Публічне адміністрування залежить від дієздатності системи публічної влади, стану суспільства, рівня та активності суспільної діяльності, оперативності та ефективності реагування на проблемні ситуації в країні [16, с. 10-11].

Встановлення та розвиток публічного адміністрування у фіскальній сфері в Україні тісно пов'язано з розвитком правового регулювання цієї сфери та 3 розбудовою державних фінансів. Публічне адміністрування у фіскальній сфері відіграє надзвичайно важливу роль. Так, рівень розвитку кожної держави залежить від іï фінансового потенціалу, особливостей його нагромадження, від пріоритетних напрямів використання [17, с. 84]. Загалом публічне адміністрування у фіскальній сфері об'єднує в собі чотири категорії: політичну, правову, управлінську, професійну [18, с. 8]. 
Держава для впливу на економічний розвиток, досягнення стійкого розвитку економіки об'єктивно змушена застосовувати весь набір наявних у неї інструментів і методів державної політики. Будучи політичною діяльністю держави та іï органів, яка спрямована на забезпечення порядку в суспільстві, узгодження і підпорядкування різноманітних соціальних інтересів, досягнення суспільної злагоди та організації управління розвитком суспільних процесів, державна політика спрямована на задоволення інтересів різних груп населення, узгодження ї і консолідації суспільства, запобігання загостренню конфліктів між різними суспільними групами [19, с. 116].

Державна політика відіграє надзвичайно важливу роль $\mathrm{y}$ суспільному житті і покликана своєчасно виявляти назрілі проблеми розвитку суспільства, аналізувати їх, встановлювати причини виникнення, складнощі та знаходити шляхи вирішення цих проблем. Саме у сфері державної політики приймаються відповідні державно-політичні рішення, розробляеться певний інструментарій, створюється механізм їх реалізаціі [20, с. 5]. Публічне адміністрування у фіскальній сфері пов'язане саме 3 фіскальною політикою, яка служить для забезпечення стабільності та стійкості національної економіки, досягнення максимально можливого добробуту суспільства шляхом створення належних умов соціально-економічної системи. Фіскальна політика дозволяє формувати податки, витрачати кошти державного бюджету для регулювання рівня ділової активності, а також для розв'язання різноманітних соціальних проблем, тобто спрямована на регулювання доходів і видатків держави [21, с. 62]. Таким чином, публічне адміністрування $є$ владним механізмом впровадження державної фіскальної політики і аналізу взаємодії його складників та впливу на суспільну дійсність [20, с. 52].
Як публічна, професійна, політично неупереджена діяльність публічне адміністрування у фіскальній сфері це сукупність дій державних службовців, які здійснюються 3 метою забезпечення виконання завдань i функцій держави [22]. Публічне адміністрування у фіскальній сфері розкриває основні напрями цілеспрямованої діяльності суб'єктів владних повноважень щодо виконання адміністративних зобов'язань [23, с. 214]. Від професіоналізму та компетентності працівників органів державної влади залежить належне виконання покладених на органи державної влади завдань, досягнення національних цілей та інтересів.

Публічне адміністрування у фіскальній сфері створюється і обмежується саме за допомогою правового регулювання, при цьому «органи державної влади та органи місцевого самоврядування, їх посадові особи зобов'язані діяти лише на підставі, в межах повноважень та у спосіб, що передбачені Конституцією та законами України» [24] із дотриманням принципів верховенства права, законності, професіоналізму, доброчесності, ефективності, політичної неупередженості та прозорості [22]. Таким чином, публічне адміністрування у фіскальній сфері можна розуміти як діяльність публічних адміністрацій, спрямовану на формування та реалізацію фіскальної політики, тобто політики у сфері регулювання доходів і видатків державного бюджету.

Складниками змісту публічного адміністрування у фіскальній сфері є:

1) формування фіскальної політики;

2) запровадження законодавчих актів та підзаконних нормативно-правових актів, що регулюють відносини у фіскальній сфері;

3) реалізація фіскальної політики та координація діяльності;

4) вжиття заходів, спрямованих на організацію діяльності публічної адміністрації (впорядкування органі- 
заційно-штатної структури, кадрового забезпечення, здійснення діловодства тощо).

Нині сталі державні фінанси $є$ головним викликом управління для всіх країн світу, саме тому багато держав проводять реформи у сфері управління державними фінансами. В такому аспекті Україна не є винятком.

Нестабільність правової регламентації податкових і бюджетних відносин, складність адміністрування податків, порушення принципів стабільності, збалансованості, обгрунтованості, справедливості і неупередженості призвели до негативного впливу фіскальної політики на стан національної економіки, до низького рівня податкової системи, неефективного використання бюджетних коштів [25, с. 262].

Натепер система управління державними фінансами в Україні спрямована насамперед на здійснення контролю за витратами, що змушує осіб, відповідальних за надання державних послуг, зосереджувати свої зусилля на дотриманні вимог, приділяючи меншу увагу підвищенню ефективності надання послуг [26]. Тому подальший розвиток системи державних фінансів в Україні відповідає не лише об'єктивним економічним закономірностям, а й запитам українського суспільства, викликає необхідність у зміцненні позицій держави, посиленні потенціалу державних фінансів і підвищенні ефективності державних регуляторних механізмів $[17$, c. 84$]$

Перспективним у подальшому $€$ наукова розробка питань, пов'язаних зі встановленням i розвитком правового регулювання публічного адміністрування у фіскальній сфері, сфері адміністративних послуг та е-урядування.

У cтатmі розглянуто теоретичні засади та підходи до визначення публічного адміністрування у фіскальній сфері. Доведено, що виникнення та застосування поняття «публічне адміністрування» пов'язане з посиленням ролі публічних засад у суспільному житті, розвитком людиноцентристської моделі суспільства, процесом трансформації системи державного управління, а також з адаптацією законодавства України до законодавства Європейського Союзу.

Зазначено, щзо публічне адміністрування у фіскальній сфері об'єднуе в собі чотири категорії: політичну, правову, управлінську, професійну. Публічне адміністрування є владним механізмом впровадження державної фіскальної політики $i$ аналізу взаємодї його складників та впливу на суспільну діяльність.

Аналіз різних теоретичних підходів дав можливість зробити висновок, що публічне адміністрування у фіскальній сфері можна розуміти як діяльність публічних адміністрацій, спрямовану на формування та реалізацію фіскальної політики, тобто політики у сфері регулювання доходів $i$ видатків Державного бюджету.

Виділено складники змісту публічного адміністрування у фіскальній сфері, до яких віднесено формування фіскальної політики; запровадження законодавчих актів та підзаконних нормативно-правових актів, які регулюють відносини у фіскальній сфері; реалізацію фіскальної політики та координацію їі діяльності; вжиття заходів, спрямованих на організацію діяльності публічної адміністрації (впорядкування організаційно-итатної структури, кадрове забезпечення, здіиснення діловодства тощо).

Ключові слова: публічне адміністрування, управління державними фінансами, фіскальна політика, фіскальна сфера держави, публічна адміністрація. 


\section{Ishchuk L. Public administration in the fiscal field: theoretical bases and approaches to definition}

The article considers the theoretical foundations and approaches to the definition of public administration in the fiscal field. It is proved that the emergence and application of the concept "public administration" related to strengthening the role of the public started in public life, the development model of society, where the person is in the center, with the transformation process of the public administration system, as well as with the process of adaptation of Ukrainian legislation to the legislation of the European Union.

It is stated that the public administration in the fiscal sphere combines four categories: political, legal, managerial, professional. Public administration is a powerful mechanism for implementing state fiscal policies and analyze the interaction of its components and effects on social activities.

The analysis of the different theoretical approaches is given the opportunity to conclude that public administration in the fiscal field can be understood as the activities of public administrations, which is aimed at the formation and implementation of fiscal policy, i.e. the policy in the sphere of regulation of incomes and expenditures of the state budget.

It is selected components of the content of public administration in the fiscal field, which include the formation of fiscal policy; the introduction of legislative acts and subordinate normative legal acts regulating relations in the fiscal field; implementation of fiscal policy and coordination; adoption of measures which are directed on the organization of public administration (streamlining the organizational structure, staffing, implementation record keeping, etc.).

Key words: public administration, public financial management, fiscal policy, the fiscal sphere of the state and public administration.

\section{Література}

1. Bступ до публічного адміністрування : навчальний посібник / Н.Л. Гавкалова, Т.А. Власенко, Л.Ю. Гордієнко та ін.; за заг. ред. д-ра екон. наук, професора Н.Л. Гавкалової. Харків : ХНЕУ ім. С. Кузнеия, 2016. 372 с.

2. Колесникова О.К. Публічне адміністрування в Україні: огляд літературних джерел. Теорія та практика державного управління. 2013. Bun. 3(42). URL: http: / / www.kbuapa.kharkov.ua/e-book/ tpdu/2013-3/doc/1/16.pdf.

3. Енииклопедія державного управління: у $8 \mathrm{~m}$. / Національна академія державного управління при Президентові України. К. : НАДУ, 2011. Т. 8: Публічне врядування / Львівський регіональний інститут державного управління Національної академії державного управління при Президентові України. Львів : ЛРІДУ НАДУ, 2011. $630 \mathrm{c}$.

4. Про Загальнодержавну програму адаптації законодавства України до законодавства Європейського Союзу : Закон України від 18.03.2004 № 1629-IV (дата оновлення: 04.11.2018). URL: https: / / zakon.rada.gov.ua/laws / show/1629-15 (дата звернення: 16.07.2020).

5. Про Стратегію сталого розвитку «Украӥна-2020» : Указ Президента України від 12.01 .2015 № 5/2015.URL:https: / / zakon.rada.gov.ua/ laws/show/5/2015\#Text.

6. Авер'янов В.Б. Реформування українського адміністративного права: необхідність переосмислення теоретичних постулатів. Актуальні проблеми держави і права. 2003. Bun. 19. C. 6-12.

7. Кузьменко О.В. Правова детермінація поняття «публічне адміністрування». Юридичний вісник. 2009. № 3(12). С. 20-25.

8. Енициклопедичний словник з державного управління / уклад.: Ю.П. Сурмін, В.Д. Бакуменко, А.М. Михненко та інші; за ред. Ю.В. Ковбасюка, В.П. Трошинського, Ю.П. Сурміна. К. : НАДУ, 2010. $820 \mathrm{C}$.

9. Оржель О. Европеїзація систем публічного адміністрування країн Центральної та Східної Європи у контексті підготовки до иленства в ЄС. Вісник Національної академії державного управління. 2010. № 2. С. 22-30.

10. Кирилюк Р. Державна судова адміністрація: 10 років судового адміністрування. 
Вісник Державної судової адміністрації України. 2012. № 3(24). С. 2-5.

11. Енииклопедія державного управління: у $8 \mathrm{~m}$. / Наи. акад. держ. упр. при Президентові України. К. : НАДУ, 2011. T. 1: Теорія державного управління, 2011. $748 \mathrm{c}$.

12. В.М. Сороко. Результативність та ефективність державного управління $і$ місиевого самоврядування : навч. посіб. / К. : НАДУ, 2012. 260 с.

13. Яковлев І.П. Форми $і$ методи публічного адміністрування у державній митній справі : дис. канд. юрид. наук. Спец.: 12.00.07 / Національний університет «Одеська юридична академія». Oдеса, 2016. 224 c.

14. Чернещький Є.Є. Публічне адміністрування заохочень: автореф. дис. канд. юрид. наук. Спеи.: 12.00.07 / Національна академія внутрішніх справ. К., 2011.21 c.

15. UN public administration glossary. URL: http: / / wwr.unpan.org / DPADM/ ProductsServices / Glossary / tabid / 1395 / language/en-US/Default.aspx (Jama звернення: 16.07.2020).

16. Бакуменко В.Д. Публічне адміністрування як процес вироблення, прийняття та виконання управлінських рішень. Наукові розвідки з державного та муніципального права. 2015. № 1. C. 8-26. URL: http: / / nbuv.gov.ua/ UJRN/Nrzd_2015_1_3.

17. Державні фінанси $і$ сталий людський розвиток: концептуальні домінанти та діалектична єдність : монографія. Тернопіль : Економічна думка. THEV, 2016. $414 \mathrm{c}$.

18. Нагаєв В.М. Публічне адміністрування : електронний навчальний посібник. Х. : ХНАУ, 2018. 278 c.
19. Логунова М.М., Шахов В.А., Шевченко М.Ф. Кониептуальні засади теоріі політики : навчальний посібник. Київ, 1999. $160 \mathrm{c}$.

20. Тертичка В. Державна політика: аналіз та здійснення в Україні. Київ : Видавництво Соломії Павличко «Основи», 2002. 750 c.

21. Дуліба Є.В. Фіскальна функиія держави: адміністративно-правовий аспект : монографія; під заг. ред. В.I. Курила. Ніжин : НДУ ім. М. Гоголя, 2018. $355 \mathrm{c}$

22. Про державну службу : Закон України від 10.12.2015 № 889-VIII. Дата оновлення: 25.05.2020. URL: https: / / zakon.rada.gov.ua/laws / show / 889-19 \# Text (дата звернення: 16.07.2020).

23. Курс адміністративного права України : підручник / В.К. Колпаков, О.В. Кузьменко, І.Д. Пастух /ma інші) / за ред. В.В. Коваленка. К. : Юрінком Iнтер, 2012. 808 c.

24. Конституиія України від 28.06.1996 № 254к/96-ВР. Дата оновлення: 01.01.2020. URL: https://zakon.rada.gov.ua/laws / show / $254 \%$ D0\% BA / $96-\%$ D0\% B 2\% D1\%80\#Text (дата звернення: 16.07.2020)

25. Дуліба Є.В. Фіскальна функиія держави: адміністративно-правовий аспект : дис. д-ра юрид. наук: 12.00.07 / Дніпропетр. держ. унів. внутр. справ. Дніпро, 2019, 390 c.

26. Про схвалення Cтратегіi реформування системи управління дернавними фінансами на 2017-2020 роки : розпорядження Кабінету Міністрів України від 08.02.2017 № 142-р. URL: https: / / zakon.rada.gov.ua/laws / show/142-2017-\%D1\%80 (Jama звернення: 16.07.2020). 